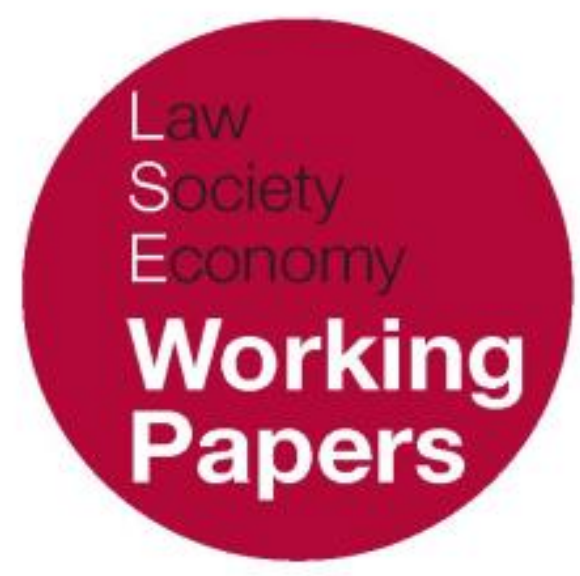

\title{
Springwell-watch: New Insights Into the Nature of Contractual Estoppel
}

\author{
Jo Braithwaite \\ LSE Law, Society and Economy Working Papers 12/2017 \\ London School of Economics and Political Science \\ Law Department
}

This paper can be downloaded without charge from LSE Law, Society and Economy Working Papers at: www.lse.ac.uk/collections/law/wps/wps.htm and the Social Sciences Research Network electronic library at: https://papers.ssrn.com/sol3/papers.cfm?abstract_id=2983850. (C) Jo Braithwaite. Users may download and/or print one copy to facilitate their private study or for non-commercial research. Users may not engage in further distribution of this material or use it for any profit-making activities or any other form of commercial gain. 


\title{
Springwell-watch: New Insights Into the Nature of Contractual Estoppel
}

\author{
Jo Braithwaite*
}

\begin{abstract}
Over the last ten years, the emergence of contractual estoppel has been catalysed by litigation between sophisticated participants in the financial markets. Pending a Supreme Court decision, the principal authority remains the Court of Appeal's 2010 decision in Springwell Navigation Corp v JP Morgan Chase Bank ('Springwell'). It would be wrong, however, to think that the doctrine has remained static since this landmark decision, or that it has remained confined to the financial sphere, or to relationships between sophisticated parties. The paper aims to fill a gap by considering the more recent, 'second generation' of cases involving contractual estoppel handed down in the five years 2013-2017 inclusive, with the aims of developing our understanding of this type of estoppel and examining its actual implications to date. Overall, the paper shows how contractual estoppel has become a recurrent and predictable feature of financial markets litigation, but also how it has spread into cases involving more diverse aspects of business and personal life. It argues that this diversity matters not only because of the impact on these wide-ranging types of relationships, but also because it has influenced the development of the doctrine. In this respect, the analysis shows how existential questions about contractual estoppel have faded from the cases, to be replaced by debates about the constraints on the doctrine. As a result, having assessed the extent and implications of spread of the doctrine, the paper proceeds to analyse the status of those constraints as they currently stand, considering in turn the 'internal' and 'external' limits.
\end{abstract}

* Associate Professor of International Commercial Finance Law, Department of Law, London School of Economics and Political Science. 


\section{INTRODUCTION}

Over the last ten years, the emergence of contractual estoppel has been catalysed by litigation between sophisticated participants in the financial markets. The new doctrine was firmly established by two Court of Appeal decisions arising out of the 1998 Russian debt crisis: Peekay Intermark $v$ Australia and New Zealand Banking Group ('Peekay') ${ }^{1}$ and Springwell Navigation Corp v JP Morgan Chase Bank ('Springwell'). ${ }^{2}$ It was subsequently developed as the English courts dealt with the wave of banking litigation triggered by the 2008 global financial crisis and with other multi-faceted claims alleging the mis-selling of financial products. ${ }^{3}$ As a result of these financial cases, it is now 'very clear't that what has been labelled as 'Springwell estoppel' 5 arises where parties agree in a contract that a particular state of affairs exists, preventing them from asserting that the opposite is true. For example, if a party agrees in a contract that it is sophisticated and that it understands the financial product it is buying, it will be unable to argue otherwise later on. Furthermore, it is clear that the maker of such statements will be bound by them, regardless of whether they are true or not. As has been repeatedly demonstrated in financial markets litigation, contractual estoppel can therefore provide an almost impenetrable line of defence.

Pending a Supreme Court decision on contractual estoppel, the principal authority remains Springwell. It would be wrong, however, to think that the doctrine has remained static since this landmark decision, or that it has remained confined to the financial sphere, or to relationships between sophisticated parties. The paper aims to fill a gap by considering the more recent, 'second generation' of cases involving contractual estoppel handed down in the five years 2013-2017 inclusive, with the aims of developing our understanding of this type of estoppel and examining its actual implications to date. This start date has been chosen to pick up the story after the initial wave of litigation which helped to establish the doctrine set out in Springwell and Peekay, and in order to develop those academic analyses which responded to these foundational cases. ${ }^{6}$ Overall, the analysis of

\footnotetext{
1 [2006] EWCA Civ 386.

2 [2010] EWCA Civ 1221.

3 Including, for example, Standard Chartered Bank v Ceylon Petroleum Corporation [2011] EWHC 1785

(Comm) and the subsequent unsuccessful appeal [2012] EWCA Civ 1049 and Grant Estates Limited $v$ RBS

[2012] CSOH 133. The former claim was brought by the bank against its counterparty for sums owing under swaps referencing the oil price. The large sums had built up 'as the world financial crisis deepened, resulting in an unprecedented and almost complete collapse of the oil price.' [2011] EWHC 1785 at [7].

The latter claim arose out of an interest rate swap entered into by a property development company and its bank. The economic downturn had triggered financial difficulties for property companies such as GEL, and the company's losses mounted under the swap because of the 'sharp fall in interest rates in 2008 and their low level thereafter' Grant Estates Limited v RBS [2012] CSOH 133 at [1] and [4] respectively.

4 Thornbridge Ltd v Barclays Bank Plc [2015] EWHC 3430 (QB) at [109].

${ }^{5}$ Regione Piemonte v Dexia Crediop SpA [2014] EWCA Civ 1298 at [116] and [120].

${ }^{6}$ Including G. McMeel, 'Documentary fundamentalism in the senior courts: The myth of contractual

estoppel' (2011) LMCLQ 185; A. Trukhtanov, 'Exclusion of liability for pre-contractual
} 
these later cases suggests that while contractual estoppel has become a wellestablished and predictable feature of financial cases, it is also being asserted in numerous, increasingly diverse disputes and that outside its original financial markets context, the effects are more constrained than might be expected.

The organisation of this paper is as follows. Part 2 considers the spread of the doctrine from 2013 to date, and it identifies various categories of 'second generation' cases. The analysis demonstrates empirically that contractual estoppel is now a well-established defence within certain types of financial markets litigation. It also shows that in this period contractual estoppel arguments have been spreading into new territory, including into cases involving more diverse types of financial contracts and agreements of a 'everyday' nature. Looking indepth at this range of cases, Part 2 shows that certain themes emerge. Most notably, existential questions about the doctrine have faded away in recent litigation and, at the same time, the debate has shifted to the constraints upon the doctrine. This is undoubtedly the principal issue with which the courts now grapple when they are required to consider contractual estoppel. As a result, having assessed the extent and implications of spread of the doctrine, the remainder of the paper analyses the status of those constraints as they currently stand.

Parts 3 and 4 of the paper look at the nature, basis and adequacy of the limits to contractual estoppel. Part 3 looks at the limits arising from within the parties' contract itself (the 'internal' limits) and Part 4 at the limits which apply exogenously, including public policy and statute (the 'external' limits). Collectively, these parts of the paper show that while it is still correct to assume that the foundational, financial cases define the doctrine of contractual estoppel, more recent and more 'everyday' cases play an important role in developing the doctrine by clarifying the various grounds on which it may be constrained.

\section{THE SPREAD OF SPRINGWELL ESTOPPEL}

The recent cases which feature Springwell estoppel can be organised into three categories. The first involves high-stakes financial transactions, often documented on standardised terms, entered into by sophisticated, international counterparties. In these cases, the facts, underlying agreements and legal arguments track Peekay and Springwell closely, and as a result, contractual estoppel features in tried and tested ways. The second category diverges, in certain respects, from this paradigm. It also involves financial contracts, but of more diverse types, and often the entities involved are less sophisticated and UK-based. Thirdly, there is a category of cases involving disparate, non-financial and sometimes genuinely everyday

misrepresentation: a setback' (2011) 127 LQR 345; J. Braithwaite, 'The origins and implications of contractual estoppel' (2016) 132 LQR 120. 
contracts, where contractual estoppel is starting to feature in novel ways. These new contexts give rise to unprecedented and testing questions about the impact of this doctrine outside the financial sphere.

The rest of this part of the paper explores these recent cases in more depth, with two objectives in mind. First, this analysis offers an accurate way of testing the actual impact of contractual estoppel in practice. Secondly, the discussion shows how the development of doctrine is heavily influenced by the different contexts in which it is raised. Accordingly, a better understanding of the nature of the cases leads to a more precise account of the doctrine itself. As this part of the paper shows, whilst sophisticated litigants tend to battle over the extent to which standardised contractual terms defeat private law claims, consumers are likely test the counter-effects of protective legislation and disputes about 'everyday' contracts raise important issues of public policy, for example where an employee or vulnerable person is involved. Put another way, the approach in this part of the paper acknowledges what Anthony Giddens called a 'double hermeneutic'7 between the development of the doctrine and the world of its users. The analysis below considers both sides of this two-way relationship, and does not just look to the cases to extract the rules making up the new doctrine.

\subsection{CLASSIC CASES}

The 'classic' cases handed down between 2013 and 2017 follow the Peekay and Springwell template closely, in terms of their fact patterns, principal legal arguments and specific contractual language from which an estoppel is alleged to arise. This template involves a sophisticated party ${ }^{8}$ which has entered into a financial contract, or contracts, with an investment bank, typically on standard terms, whereby the party makes an investment or enters into a complex product designed to hedge a risk or speculate about the future. Very often, the relevant contracts include the bank's mandate letter and the ISDA Master Agreement (the 'ISDA MA'), which is a contract drafted by a highly influential trade association for the derivatives markets, used to document the overwhelming majority of 'over the counter' derivatives worldwide. The ISDA MA is designed to be used without significant amendment (elections are made in the Schedule to the MA, while separate Confirmations document the economic terms of each transaction entered into under the MA)9 and was therefore described in one judgment as 'a standard

\footnotetext{
7 A. Giddens, Social Theory and Modern Sociology (Cambridge: Polity Press, 1987) 20-21 and 30-31.

${ }^{8}$ Customers often challenge the suggestion that they were a sophisticated entity for these purposes. However, these arguments are rarely successful, not least because of contractual statements to the contrary. See, for e.g., Regione Piemonte v Dexia Crediop SpA [2014] EWCA Civ 1298 at [122], rejecting the local authority's claim that it was, in fact, not a qualified investor for the purposes of the relevant Italian Regulation.

${ }^{9}$ For an overview of the derivatives markets and a discussion of the importance and use of the ISDA documentation, see J. Benjamin, Financial Law (Oxford: OUP, 2007) section 4.4 and ISDA's website,
} 
term or "boiler plate" document'. ${ }^{10}$ By way of example, several of the cases in Table 1 arise out of the Italian local authority of Piedmont's entering into interest rate derivatives 'on the standard ISDA form'11 in order to manage the risk associated with bonds it had issued. Overall, Table 1 shows that eight decisions in this category in the period 2013-2017 have directly involved the ISDA MA, while two more involve interest rate derivatives, though these judgments do not specify if the ISDA terms were used.

Typically, exogenous events such as plummeting global interest rates, the collapse in oil prices, or the Russian Government's 1998 debt moratorium lie behind the litigation in this category. These global events left certain investments worthless, or shifted the value of derivatives so that very large sums fell due from counterparties to banks. In one case, the collapse in interest rates meant that the sum claimed from an Italian local authority under its derivatives transactions amounted to 36 million euro. ${ }^{12}$ These developments, in turn, set the scene for complex, multi-faceted claims by which the bank's counterparty seeks to have its contracts declared void, or to win damages, or to avoid paying the sums which, on the face of the deal, it owes the bank. As seen in Springwell itself, these parallel claims routinely include misrepresentation, fraud, breach of duty, breach of fiduciary duty, breach of contract, breach of collateral contract and, depending on the nature of the party, a claim for breach of statutory duty under section 138D of the Financial Services and Markets Act $2000^{13}$ and the claim that the contract was ultra vires all along. Given the lack of success of the arguments that these types of entities are 'private parties' for the purpose of section 138D, ${ }^{14}$ these claims test the capacity of private law to assist parties which have very little protective financial regulation to fall back upon.

Ultimately, however, the myriad of private law claims does little to assist the claimants in these cases. Contractual estoppel is not the only reason for this; often, evidential requirements are simply not made out, so claims fail before estoppel becomes an issue. ${ }^{15}$ Nonetheless, over the course of Peekay, Springwell and the similar financial cases which followed, contractual estoppel has emerged as one of the most effective defences available to banks involved in this type of litigation. In particular, widely used contractual statements that the bank's counterparty was sophisticated, understood the risks, read the documents, was owed no fiduciary

\footnotetext{
'Legal and Documentation', available at http://www2.isda.org/functional-areas/legal-anddocumentation/ (last accessed on 6 June 2017).

${ }^{10}$ Dexia Crediop SpA v Provincia Di Brescia [2016] EWHC 3261 (Comm) at [88].

${ }^{11}$ Dexia Crediop SpA v Regione Piemonte [2013] EWHC 1994 (Comm) at [21] per Eder J.

12 Ibid at [15].

${ }^{13}$ Formerly section 150 of the Financial Services and Markets Act 2000. See, e.g. Titan Steel Wheels $v$ RBS [2010] EWHC 211 (Comm), and Grant Estates Limited v RBS [2012] CSOH 133.

${ }^{14}$ Including most recently in Nextia Properties v RBS [2013] EWHC 3167 (QB) at [107].

${ }^{15}$ For example, in Barclays Bank plc v Svizera Holdings BV [2014] EWHC 1020 (Comm) the court found that there was no representation made by the bank to the defendants, and even if there had been, 'they were not relied on by the defendants', at [56]. While this finding on the evidence was 'fatal' to the misrepresentation case, the judge went on to set out that contractual estoppel would have prevented such claim anyway. Ibid at [58].
} 
duties, and neither received nor relied upon any representations have all been held to give rise to an estoppel which scuppers vital elements of claims. Similarly, entire agreement clauses have been held to give rise to contractual estoppel so that a litigant could not rely on a representation covered by that clause. ${ }^{16}$ The overall effect amounts to 'consistent judicial recognition' 17 of contractual estoppel arising from widely used defensive drafting, and results in an almost insuperable difficulty'18 for sophisticated parties trying to litigate counter to such statements.

This is not to exaggerate the effects of contractual estoppel. Of the various limits discussed in Parts 3 and 4, the caveat that the interpretation of the underlying contractual wording will circumscribe the effects of the estoppel is the most relevant here. Indeed, in at least two of these type of cases, the need to scrutinise the extent of contractual estoppel arising from particular words was identified as one reason for denying summary judgment as the issues needed determining at full trial. ${ }^{19}$ However, as already mentioned, this set of cases often deals with widely used, standardised terms. Thus, as cases in this category multiply, precedent hardens around certain familiar drafting, and the effects of contractual estoppel start becoming more predictable. It is telling, for example, that later judgments have started referring back to earlier decisions on the same clause or a similar standardised term for guidance. ${ }^{20}$ Judgments now note that certain words have certain effects in accordance with Springwell'. ${ }^{21}$ The existential questions which attracted considerable debate in Springwell and Peekay, including the detailed discussion the origins of the doctrine, and consideration of whether the latter was 'per incuriam', have fallen away for the time being. Contractual estoppel has, in this sector anyway, evolved from being a novelty into a recurrent and predictable

\footnotetext{
${ }^{16}$ For example, Regione Piemonte v Dexia Crediop SpA [2014] EWCA Civ 1298 at [116], referring to the parties' entire agreement clause as well as other statements in the parties' ISDA MA, of which the Court of Appeal held that 'in respect of all of those matters (which are statements of fact rather than characteristics of a relationship) I can see no basis upon which a Springwell estoppel would not operate. I note that one of the representations in that case was that Springwell "had not relied and acknowledges that neither CMSCA nor CMIL has made any representation or warranty with respect to the advisability of purchasing" the relevant Notes.' See also Nextia Properties v RBS [2013] EWHC 3167 (QB) at [92] and [98], confirming the effects of contractual drafting including a 'no advice' and an entire agreement clause, and for this and other reasons, granting the banks' application to strike out the property company's claim. ${ }^{17}$ Barclays Bank plc v Svizera Holdings BV [2014] EWHC 1020 (Comm) at [61].

${ }^{18}$ Dubai Islamic Bank v PSI Energy Holding Company BSC [2013] EWHC 3781 (Comm) at [31] per Flaux J, referring to the effects of an entire agreement clause on the defendant's argument that there were certain oral assurances between the parties.

${ }^{19}$ Deutsche Bank AG v Unitech Global Ltd [2013] EWHC 2793 (Comm) at [168]-[174]; Dexia Crediop SPA v Provincia di Crotone at [51].

${ }^{20}$ For example, see: (1) n 16 above, citing Regione Piemonte v Dexia Crediop SpA [2014] EWCA Civ 1298 at [116], where the court expressly refers back to a similar term in Springwell; (2) Barclays Bank plc v Svizera Holdings BV [2014] EWHC 1020 (Comm) at [59] where the judge notes that Cassa de Risparmio v Barclays Bank [2011] EWHC 484 held that contractual estoppel arose from 'a provision in similar terms to clause 10.3(c)(iii) in the present case.' This clause was a representation that the Company understood and accepts the 'terms, conditions and risk of the Transaction'; and (3) the lengthy comparison between the contractual estoppel established in Cassa de Risparmio v Barclays Bank [2011] EWHC 484, Standard Chartered Bank v Ceylon Petroleum Corporation [2011] EWHC 1785 (Comm) and the clauses in question in HSH Nordbank. AG v Intesa Sanpaolo SpA [2014] EWHC 142 (Comm), at ibid [53]-[62].

${ }^{21}$ Regione Piemonte v Dexia Crediop SpA [2014] EWCA Civ 1298 at [122].
} 
feature, now familiar enough to be referred to in shorthand as the 'Springwell principle'. ${ }^{22}$

\begin{tabular}{|c|c|}
\hline 2016 & $\begin{array}{l}\text { LSREF III Wright Ltd v Millvalley Ltd [2016] EWHC } 466 \text { (Comm) (ISDA MA) } \\
\text { Dexia Crediop SpA v Provincia Di Brescia [2016] EWHC } 3261 \text { (Comm) (ISDA MA) } \\
\text { Taberna Europe CDO II Plc v Selskabet (formerly Roskilde Bank A/S) (in bankruptcy) } \\
\text { [2016] EWCA Civ } 1262 \\
\text { Property Alliance Group Ltd v RBS [2016] EWHC } 3342 \text { (Ch) (ISDA MA) }\end{array}$ \\
\hline 2015 & $\begin{array}{l}\text { Taberna Europe CDO II Plc v Selskabet (formerly Roskilde Bank A/S) (in bankruptcy) } \\
\text { [2015] EWHC } 871 \text { (Comm) }\end{array}$ \\
\hline 2014 & $\begin{array}{l}\text { UBS AG v Kommunale Wasserverke Leiprig AG GmbH [2014] EWHC } 3615 \text { (Ch) } \\
\text { (ISDA MA) } \\
\text { Regione Piemonte v Dexia Crediop SpA [2014] EWCA Civ } 1298 \text { (ISDA MA) } \\
\text { Credit Suisse International v Stichting Vestia Groep [2014] EWHC } 3103 \text { (Comm) (ISDA } \\
\text { MA) } \\
\text { Barclays Bank plc v Svizera Holdings BV [2014] EWHC } 1020 \text { (Comm) } \\
\text { HSH Nordbank. AG v Intesa Sanpaolo SpA [2014] EWHC } 142(\mathrm{Comm}) \text { (ISDA MA) }\end{array}$ \\
\hline 2013 & $\begin{array}{l}\text { Nextia Properties } v \text { UBS [2013] EWHC } 3167 \text { (QB) (concerning an interest rate swap, } \\
\text { which the decision suggests was not documented using the ISDA MA) } \\
\text { Dexia Crediop SpAv Regione Piemonte [2013] EWHC } 1994 \text { (Comm) (Eder J) (ISDA } \\
\text { MA) } \\
\text { Deutsche Bank, AG v Unitech Global Ltd [2013] EWHC } 2793 \text { (Comm) }{ }^{23} \text { (including } \\
\text { claims relating to an interest rate swap as well as a bank loan) }\end{array}$ \\
\hline
\end{tabular}

Table 1: Recent examples of the classic use of Springwell estoppel (noting where the litigation involved the standard ISDA Master Agreement ('MA')). ${ }^{24}$

22 Dexia Crediop SpA v Regione Piemonte [2013] EWHC 1994 (Comm) at [53].

23 Affirmed by Deutsche Bank. AGv Unitech Global Ltd [2016] EWCA Civ 119, but contractual estoppel was not considered on appeal.

${ }^{24}$ The table, and tables 2 and 3 below, include both judgments handed down after trial and decisions after interim applications for summary judgment or for a claim to be dismissed. An example of the latter is Nextia Properties v RBS [2013] EWHC 3167, where all of the claimants' various claims were dismissed. 
At the same time as confirming the effect of certain standard terms, however, some of the recent cases in this category also contain distinctive features which have helped to fine-tune our understanding of the impact of contractual estoppel on different types of sophisticated participants the financial markets. It is notable, for example, that Table 1 includes several recent decisions relating to complex, ongoing litigation between Italian local authorities ${ }^{25}$ and various banks with which they entered into derivatives transactions. ${ }^{26}$ In Regione Piemonte $v$ Dexia Crediop $S p A^{27}$ the Court of Appeal refused the Italian local authority permission to appeal from the decision of Eder J. ${ }^{28}$ Counsel for the local authority had emphasised its inexperience in this sector, the limited English language skills of key personnel and its general reliance on the banks. ${ }^{29}$ Nonetheless, the Court of Appeal confirmed that 'the Banks were entitled to rely on the principle in Springwell', 30 and specifically that contractual estoppel arose from the representation in the ISDA documentation whereby Piedmont stated that it was not relying on any communication from the Banks as investment advice or a recommendation. This was held to preclude the authority from relying on statements it alleged had created a fiduciary duty and amounted to incorrect advice. ${ }^{31}$ Moreover, in accordance with Springwell' the banks were entitled to rely on Piedmont's statement in the contractual documentation that it was a 'qualified investor' within the relevant Italian Regulation, regardless of the arguments put to the Court that in fact the contrary was true. ${ }^{32}$

In a later case involving a different Italian local authority, which was also contesting various derivatives transactions, the judge applied the Court of Appeal's decision in the Piedmont case in the context of a dispute about the English court's jurisdiction to make certain declarations about the status of the parties and their transaction. Here, the novelty was that Springwell estoppel provided a way of circumventing arguments about the impact of Italian law on interpretation of the jurisdiction clause in the parties' ISDA MA. Declarations which the bank sought from the court referenced 'contractual representations under an English law contract'. 33 This was held to mean that the English court could grant the declarations 'without making any findings about Italian law. This is because the

${ }^{25}$ Claims that the local authorities were not sophisticated entities for this purpose were unsuccessful. See, e.g., Regione Piemonte v Dexia Crediop SpA [2013] EWHC 1994 (Comm) at [54].

${ }^{26}$ Note that there are more Italian local authorities decisions than those included in Table 1, as not all involve contractual estoppel. See also, for example, Dexia Crediop v Commune di Prato [2016] EWHC 2824 (Comm)

27 [2014] EWCA Civ 1298.

28 Regione Piemonte v Dexia Crediop SpA [2013] EWHC 1994 (Comm).

${ }^{29}$ See for example, the summary of the submissions on these lines in Regione Piemonte v Dexia Crediop SpA

[2014] EWCA Civ 1298 at [106].

${ }_{30}$ Ibid at [109] (full name and reference for Springwell omitted).

${ }^{31}$ Ibid at [106]-[109] and [116].

32 Ibid at [122].

${ }^{33}$ Dexia Crediop SpA v Provincia Di Brescia [2016] EWHC 3261 (Comm) at [111]. 
declarations operate on the basis of a contractual estoppel. ${ }^{34}$ Contractual estoppel therefore provided the court with one reason (of several) for dismissing the local authority's application challenging the English court's jurisdiction. Given the nature of the dispute and the contract in question, this is a significant decision as regards the short-cutting effects of contractual estoppel.

\subsection{DiverSE FINANCIAL CASES}

This category of cases involving contractual estoppel remains broadly financial in nature, but the parties and transactions are considerably more diverse than those considered above. Whereas the cases in the previous category concerned sophisticated parties advancing similar claims with respect to similar deals, this category is far less homogenous. In terms of the litigants involved, the cases identified in Table 2 feature smaller corporate customers of banks and ordinary individuals. The underlying deals span a sale and purchase of shares, loans from High Street banks to retail borrowers, and swap transactions between banks and small and medium sized enterprises, categorised as 'retail clients' 35 rather than as sophisticated customers. Reflecting the less international nature of most of the parties involved these cases, it is notable that this category includes decisions handed down by the District Courts in Bristol and Manchester ${ }^{36}$ and an appeal from the Nottingham County Court. ${ }^{37}$ This diversity is significant, because it complicates the purposes for which Springwell estoppel is deployed, how and if it is found to arise, and the ways in which the doctrine may be regulated.

\footnotetext{
34 Ibid at [112].

${ }^{35}$ For example, in Crestsign Ltd v National Westminster Bank Plc [2014] EWHC 3043 (Ch), the claimant was a family-run private company which invested in commercial property, categorised as a 'retail client' for the purposes of its relationship with the bank, at [54]; and in Thornbridge Ltd v Barclays Bank. Plc [2015] EWHC 3430 (QB), Barclays classified Thornbridge Ltd, also a private company as a 'retail client', at [84]. 36 Thomas v Triodos Bank NV [2017] EWHC 314, and Thornbridge Ltd v Barclays Bank Plc [2015] EWHC 3430 (QB) respectively.

${ }^{37}$ Wood v Capital Bridge Finance Ltd [2015] EWCA Civ 451.
} 


\begin{tabular}{|c|c|}
\hline 2017 & Thomas v Triodos Bank NV [2017] EWHC $314(\mathrm{QB})^{38}$ \\
\hline 2016 & Sears v Minco plc [2016] EWHC 433 (Ch) \\
\hline 2015 & $\begin{array}{l}\text { Thornbridge Ltd v Barclays Bank Plc [2015] EWHC } 3430 \text { (QB) } \\
\text { Wood v Capital Bridge Finance Ltd [2015] EWCA Civ } 451 \\
\text { NRAM Plc v McAdam [2014] EWHC } 4174 \text { (Comm); overturned by [2015] EWCA Civ } \\
751\end{array}$ \\
\hline 2014 & Crestsign Ltd v National Westminster Bank Plc and RBS [2014] EWHC 3043 (Ch) \\
\hline 2013 & $\begin{array}{l}\text { Bikam Ood v Adria Cable SARL [2013] EWHC } 1985 \text { (Comm) } \\
\text { Financial Conduct Authority v Asset LI Inc (t/a Asset Land Investment Inc) [2013] EWHC } \\
178^{39}\end{array}$ \\
\hline
\end{tabular}

Table 2: More diverse financial cases involving Springwell estoppel. 40

Contractual estoppel is deployed for a broader range of purposes in these cases than in the preceding category, though one of the most important remains its use as a tried and tested means of enforcing the defensive drafting in parties' agreements. Contractual estoppel was raised for this familiar purpose in various cases between banks and their retail customers, including Crestsign Ltd v National Westminster Bank Plc, ${ }^{41}$ Thornbridge Ltd v Barclays ${ }^{42}$ and Thomas v Triodos Bank. ${ }^{43}$ In two of these three cases, retail customers entered into loans and interest rate swaps alongside each other. In Crestsign, discussions about an interest rate swap took

\footnotetext{
38 The claimants were husband and wife owners of an organic farming business, classified as retail customers of their bank; Thomas v Triodos Bank NV [2017] EWHC 314 (QB) at [1].

39 This decision was upheld by the Court of Appeal in [2014] EWCA Civ 435 and by the Supreme Court in [2016] UKSC 17. Springwell estoppel is mentioned briefly in the High Court decision in the course of the discussion of representations, at [114]. Springwell was cited in argument at the Court of Appeal stage, but contractual estoppel does not form part of the decision at Court of Appeal or thereafter, as the representations clause in question did not cover the statements which were relevant to this dispute. The appellate-level decisions are therefore not included in Table 2.

40 Omitted from Table 2 are decisions where contractual estoppel was raised late or otherwise ineffectively by one of the parties, and not therefore considered by the judge. These late and/or failed arguments may also, however, be seen as a sign of the growing influence of the doctrine in new contexts. For example, in Sabbagh v Khoury [2014] EWHC 323 (Comm), a dispute between family members, the defendants introduced Springwell and the label of 'contractual estoppel' after the hearing had commenced, so the judge decided not to rule on the merits of this issue, at [138].

41 [2014] EWHC 3043 (Ch).

42 [2015] EWHC 3430 (QB).

43 [2017] EWHC 314 (QB).
} 
place in parallel with negotiations about the customer's credit line, and the transactions were completed in June 2008.44 In Thornbridge's case, it was a condition of the April 2008 loan that it would enter into an interest rate hedge. 45 In the economic turbulence which followed, interest rates plunged so that the swaps become extremely costly for the customers. As the judge in Crestsign noted, '[n]o one expected such steep or long-lasting base rate cuts' 46 and customers found that the break costs of swaps in these circumstances were far greater than they expected ( $£, 600,000$ in Crestsign; $£, 565,000$ in Thornbridge). The Thomas' case differed slightly, in that it arose from their switch from a variable rate loan to one where the rate was fixed for ten years, rather than from a derivative and loan combination. Their deal was struck in June 2008.

The contractual estoppel arguments in these three cases are familiar from the classic authorities, though the counterparties involved here had far less sophistication about the products they were entering into. Indeed, the banks consistently invoke the classic contractual estoppel cases ${ }^{47}$ as an important part of their defence against these 'mis-selling' claims. For example, in Crestsign, the banks 'placed heavy reliance on the documents' provided to the customer, and specifically sought to argue that contractual estoppel arose from statements that the customer was to make its own assessment of the deal and that the banks were not acting as advisers. ${ }^{48}$ Ultimately, these cases confirm the very significant effects of contractual estoppel even in the bank-retail customer context. It is the case that, even where the customer can show that there was such a gap in terms of knowledge and expertise between it and the bank that the bank owed it a duty of care according to Hedley Byrne $v$ Heller, ${ }^{49}$ the documents can be drafted 'to ensure that the duty [that would otherwise] arise, did not do so'.50 In Crestsign, contractual estoppel arose to this effect, even where the relevant documents were produced after the meeting where statements that would otherwise have amounted to advice were made. As in the classic cases, the courts' consistent justification for this outcome is 'construing the documents as meaning what they say'. ${ }^{51}$

As these cases involve retail customers, there is more a substantial discussion about whether the clauses in question are 'basis clauses' or exclusion clauses and, in the case of the latter, about the protection afforded by the reasonableness test as stated in section 11(1) of the Unfair Contract Terms Act 1977 ('UCTA'). The

\footnotetext{
${ }^{44}$ Crestsign Ltd v National Westminster Bank Plc and RBS [2014] EWHC 3043 (Ch) at [70].

45 Thornbridge Ltd $v$ Barclays Bank. Plc [2015] EWHC 3430 at [5].

${ }^{46}$ Crestsign Ltd v National Westminster Bank Plc and RBS [2014] EWHC 3043 (Ch) at [72].

47 Including the older cases not mentioned in Table 1 such as Raiffeisen Zentralbank $v$ RBS [2011] 1 Lloyd's Rep 123, cited in Crestsign Ltd v National Westminster Bank Plc and RBS [2014] EWHC 3043 (Ch) at [99]. Another example is the reliance placed on Barclays Bank v Svizera Holdings BV [2014] EWHC 1020 (Comm) in Thornbridge Ltd v Barclays Bank Plc [2015] EWHC 3430 at [106] on the basis that the Svizera judgment 'had to consider similar representations to those in this case, that the client had made its own independent decisions and the information and explanations provided were not to be considered investment advice or a recommendation to enter into the transaction.'

48 Crestsign Ltd v National Westminster Bank Plc and RBS [2014] EWHC 3043 (Ch) at [94].

49 [1964] AC 465.

${ }^{50}$ Crestsign Ltd v National Westminster Bank Plc and RBS [2014] EWHC 3043 (Ch) at [111].

51 Ibid at [116].
} 
discussion in Part 3 below, however, shows that the protection afforded by UCTA will only rarely assist claimants facing a defence based on contractual estoppel, even where there is a yawning gap in relative knowledge, skill and experience between the parties. This outcome often leaves customers facing very steep losses. While regulatory intervention in these retail markets is beyond the scope of this paper, it is significant to note that in Thomas, even voluntary regulation of the bank involved made a significant difference for the customer. In this case, the claimants were able to rely on the fact that their bank advertised that it subscribed to the Business Banking Code ('BBC') ${ }^{52}$ which is a voluntary code of practice including a fairness commitment. As the judge noted, there were no contractual basis clauses or exclusion clauses which qualified the bank's commitment to the $\mathrm{BBC}$, and this helped to inform the conclusion that the bank owed its customer an 'information duty' in this case. 53

Elsewhere in this category of cases, contractual estoppel is argued with somewhat different objectives in mind. On some occasions, the doctrine is deployed simply to hold a party to an objective fact, such as in Bikam Ood. Here, in the context of a share sale and purchase, the parties had entered into an agreement which included a stated amount net debt. In the subsequent litigation, the claimants had to show that net debt was less than that in the agreement, in order to show that they had suffered loss. The buyer's argument that they were precluded from doing so because of contractual estoppel was successful, with the judge referencing Peekay and Springwell in his description of this argument as 'well founded' as well as 'fatal' to the claim for breach of contract. ${ }^{44}$ This is a stark reminder that contractual estoppel is not only relevant to defensive drafting, even though most cases to date involve this type of clause, but that it potentially arises from any type of contractual statement.

Finally, these claims also include some genuinely novel arguments based on contractual estoppel. Most striking are the cases whereby individuals attempt to establish that the Consumer Credit Act 1974 (the 'CCA') should apply to their credit agreements with banks. NRAM plc $v$ McAdam is an important test case which affected some 41,000 borrowers with loans provided by NRAM (previously Northern Rock). ${ }^{55}$ While these loans fell outside the CCA, the documentation stated that they were regulated by the statute. The customers argued that express references to the CCA in the loan meant that the bank was estopped from denying them the benefit of the protections in the statute. In mirror-image litigation, a customer with loan documentation incorrectly stating that the loan fell outside the CCA argued that she was protected by the statute, and the lender asserted

\footnotetext{
52 Thomas v Triodos Bank NV [2017] EWHC 314 at [59]-[63].

${ }^{53} \mathrm{Ibid}$ at [81]. The judge went on to find that there had been breaches of the information duty as well as misrepresentations, though he did not find for the claimants on every point. Ibid at [125].

${ }^{54}$ Bikam Ood v Adria Cable SARL [2013] EWHC 1985 (Comm) at [160].

55 NRAM Plc v McAdam [2014] EWHC 4174 (Comm); overturned by [2015] EWCA Civ 751.
} 
contractual estoppel as part of its case that she was not. ${ }^{56}$ These cases raise a wide range of issues unrelated to contractual estoppel, but they are notable for this purpose for the unprecedented arguments about the role of the doctrine in determining regulatory protections. The effects of contractual estoppel in this regulatory context are considered in detail in part 4 below, but it is a sign of the complexity and novelty of these issues that both of these cases involved successful appeals from their respective first instance decisions.

\subsection{NON-FINANCIAL MARKETS CASES}

\begin{tabular}{|l|l|}
\hline $\mathbf{2 0 1 7}$ & First Tower Trustees Ltd v CDS (Superstores International) Ltd [2017] EWHC 891 (Ch) \\
\hline $\mathbf{2 0 1 6}$ & $\begin{array}{l}\text { Police and Crime Commissioner for Greater Manchester v Butterworth (unreported) } \\
\text { November 2016 }\end{array}$ \\
\hline $\mathbf{2 0 1 5}$ & \begin{tabular}{l} 
Startwell Ltd v Energie Global Brand Management Ltd [2015] EWHC 421 (QB) \\
Richards v Wood and Wood [2014] EWCA Civ 32757 \\
First Subsea Ltd v Balltec Ltd [2014] EWHC 866 (Ch) \\
Hardy v Griffiths [2014] EWHC 3947 (Ch) \\
Littlewoods Retail Ltd v The Commissioners for HMRC [2014] EWHC 868 (Ch) ${ }^{58}$ \\
\hline $\mathbf{2 0 1 3}$
\end{tabular} \\
\hline
\end{tabular}

Table 3: Non-financial market cases involving Springwell estoppel.

This third category of cases demonstrates how arguments based on contractual estoppel have spread outwards from the financial sector into many different areas of business and personal life. The subject-matter in this category is diffuse, spanning a dispute worth $£ 1$ billion in relation to overpaid VAT, 59 and litigation between a couple and their son-in-law about the proceeds of the sale of a house. There is also real variety within the cases involving individuals, which, in addition

\footnotetext{
56 Wood v Capital Bridge Finance Ltd [2015] EWCA Civ 451.

57 On appeal from Manchester County Court.

58 Part of a long-running dispute between Littlewoods and HMRC, arising from overpayments of VAT by Littlewoods. The dispute centered on the correct approach to the quantification of Littlewoods' claim. The Court of Appeal affirmed the decision of Mr Justice Henderson, at [2015] EWCA Civ 515 and at the time of writing, the matter is currently under appeal to the Supreme Court. However, the Court of Appeal judgment did not refer to Littlewoods' arguments based on contractual estoppel made at first instance.

${ }^{59}$ Littlewoods Retail Ltd v The Commissioners for HMRC [2014] EWHC 868 (Ch).
} 
to Richards $v$ Woods and Woods, ${ }^{60}$ include a dispute over a settlement agreement between a client and an auction house; ${ }^{61}$ litigation between a company and certain former employees; ${ }^{62}$ an appeal from the Pensions Ombudsman about the terms of a compromise agreement between an employee and a police authority; 63 and litigation between individuals about the sale of a country manor. ${ }^{64}$

This more diffuse category of cases is significant for two reasons. First, it confirms that even in varied, non-financial contexts involving ordinary individuals, the authorities are clear that contractual estoppel remains a valid and binding doctrine which will operate unless a specific limitation applies. For example, in Richards, a declaration of trust between a couple and their son-in-law stated that each party contributed part of the purchase price of a house under the right to buy scheme even though, in fact, the son-in-law had contributed the whole sum. In litigation some twenty five years later, counsel for the son-in-law submitted that the interpretation of the declaration of trust should reflect the parties' actual financial contributions at the time of the purchase. This argument was rejected outright by the unanimous Court of Appeal, which held on the basis of contractual estoppel that the actual arrangements should be ignored when interpreting the deed. The Court held that

All parties are bound by the agreed statement, whether it represented the truth or not. This is the traditional function of recitals which in this respect are part of a sub-species of estoppel known as contractual estoppel. ${ }^{65}$

The second insight from this set of cases, however, is that, while the fundamental validity of contractual estoppel is not questioned in these cases, the limits of its application are. The use of contractual estoppel arguments in diffuse contexts has generated new questions around its limitations, whether regarding the impact of public policy (in the employment and in the pensions setting), statute (raised in relation to the statutory settlement between Littlewoods and HMRC and the CCA cases) or fraud. For this reason, many of latest developments around the external limits to the doctrine, analysed in Part 4 of the paper, are driven by these diffuse, non-financial cases. Such cases may have a lower profile in the debate about contractual estoppel than the classic banking decisions, but they are key to this phase of the development of the doctrine.

60 [2014] EWCA Civ 327.

${ }^{61}$ Bonhams 1793 Ltd v Cavazzoni [2014] EWHC 682 (Ch).

62 First Subsea Ltd v Balltec Ltd [2014] EWHC 866 (Ch).

${ }^{63}$ Police and Crime Commissioner for Greater Manchester v Butterworth (unreported) 10 November 2016.

${ }^{64}$ Hardy v Griffiths [2014] EWHC 3947 (Ch).

${ }^{65}$ Richards $v$ Wood and Wood [2014] EWHC Civ 327 at [15] per Lewison LJ. 


\section{INTERNAL LIMITS}

Contractual estoppel is dependent on, and defined by, the underlying contract. Springwell expressly confirmed that the doctrine requires a valid contract and that, unlike other forms of estoppel, it does not require the representee to show detrimental reliance or unconscionability. As Briggs LJ concluded in a unanimous 2015 Court of Appeal decision, ' $(t)$ he essence of contractual estoppel, as it is now understood, is that it has contractual force.' 66 This divergence from the estoppel paradigm has sometimes been questioned in the cases ${ }^{67}$ and scholarship, ${ }^{68}$ but in this respect, it is not unique. Significantly, the Privy Council has recently confirmed that these factors play no part in estoppel by deed either. ${ }^{69}$

While this makes it easier to assert contractual estoppel than the more classic estoppels such as estoppel by representation, there are two sides to this coin. Recent cases graphically demonstrate how both the role and extent of contractual estoppel may be thrown into doubt over the course of disputes about the validity, interpretation and classification of the underlying contract. Accordingly, this part of the paper explores the significant regulatory effects of contractual estoppel's relationship with the underlying contract.

\subsection{DePENDENCE ON THE CONTRACT}

Contractual estoppel will not be available if the underlying contract, or the relevant part of it, is unenforceable, or if the relevant statements fall outside of the parties' agreement. As a result, challenging the status of the parties' contract is one way of undermining an argument based on contractual estoppel. In Roberts $v$ Egan, for example, an investment advisor's attempt to rely upon defensive drafting in a membership agreement (including a non-reliance clause) was held to be doubtful because the investor had not receive a copy of the agreement until after he made his investment and at the relevant time had 'no express knowledge' of the relevant term. ${ }^{70}$ Even where the relevant statement is inarguably part of the a binding contract, it follows that any contractual estoppel will be subject to a successful claim for rectification of the contract. This is because the true agreement between the parties 'is to be found in the rectified contract' and it must be correct that, given contractual estoppel's dependence on the parties' agreement, it cannot operate to preclude rectification. ${ }^{71}$

\footnotetext{
${ }^{66}$ Wood v Capital Bridging Finance Ltd [2015] EWCA Civ 451, [31].

${ }^{67}$ For example, in Credit Suisse International v Stichting Vestia Groep [2014] EWHC 3103 (Comm) at [309].

${ }^{68}$ For example, S. Wilken and K. Ghaly, The Law of Waiver, Variation and Estoppel, $3^{\text {rd }}$ ed (Oxford: OUP, 2012) 10-11.

69 Prime Sight v Lavarello [2013] UKPC 22.

70 Roberts v Egan [2014] EWHC 1849 (Ch), [38]. The status of the contract between the parties was not explored further in this ex tempore judgment, as the judge found that in fact no material misrepresentations were made to the investor [70].

${ }^{71}$ LSREF III Wight Ltd v Millvalley Ltd [2016] EWHC 466 (Comm) at [123].
} 
By far the most significant way in which the binding nature of financial contracts may be challenged is on the basis that they are ultra vires one of the parties. In the financial markets context both public ${ }^{72}$ and quasi-public ${ }^{73}$ bodies have successfully argued that certain deals were beyond their capacity and therefore void. The fact that such arguments would now also defeat contractual estoppel may provide a further incentive assert them. Where a contract is ultra vires one of the parties, contractual estoppel will not arise; nor can the doctrine alter this outcome, regardless of any statements about capacity which were made in the original contract. ${ }^{74}$ As Andrew Smith J put it in Stichting Vestia Groep, 'an entity cannot achieve what it has no power to do simply by stating or promising that it has the power'. ${ }^{75}$ The doctrine may, however, complicate the question of whether there is a valid contract. This is most obviously the case where, as in Stichting Vestia Groep, parties have entered into a valid ISDA MA to facilitate multiple deals between them and only some of the underlying transactions are found to be ultra vires.

Stichting Vestia Groep was identified as a 'classic' contractual estoppel case in the preceding discussion, as it involved a dispute between a bank and a Dutch social housing association (SHA), where the bank claimed over $€ 83$ million from the SHA with respect to derivatives documented using the 2002 version of the ISDA MA. While the MA was 'undoubtedly valid'76 some, but not all, of the transactions entered into under it were held to be speculative and therefore ultra vires the SHA. The relevant drafting was in the Additional Representations part of the Schedule to the MA, which was held to mean that the parties promised that each transaction entered into subject to the MA is and will be in compliance with its articles of association $\ldots$ and other laws or regulations applicable to [SHA] from time to time' and that it was 'entering into each Transaction for the purpose of hedging its exposures ... ${ }^{77}$ Furthermore, it was held that this drafting must have been intended by the parties to cover both valid and invalid transactions, otherwise it would be 'to attribute an absurd intention to the parties'. ${ }^{78}$ It followed that the bank was entitled to enforce the MA as if the ultra vires transactions were binding and valid. ${ }^{79}$ Contractual estoppel did not, therefore, extend the capacity of SHA so as to make invalid deals valid, but it produced an outcome which was the same as if it had.

\footnotetext{
72 In well-known English litigation, numerous borough councils were found to have entered into financial transactions outside their powers under section 111 of the Local Government Act 1972, see, e.g., Hazell v Hammersmith and Fulham LBC [1992] 2 AC 1.

73 See, for e.g., Credit Suisse International v Stichting Vestia Groep [2014] EWHC 3103 (Comm).

74 This is the 'bootstraps' argument dismissed by Hobhouse J in W estdeutsche Landesbank Girozentrale $v$ Islington LBC [1994] 4 All ER 890, 950b, cited with approval in Credit Suisse International v Stichting Vestia Groep [2014] EWHC 3103 (Comm) at [293].

75 Ibid at [319].

76 Ibid at [315].

77 Ibid at [291].

78 Ibid at [315]

${ }^{79} \mathrm{Ibid}$ at [319].
} 
Stichting Vestia Groep is important because it suggests that a contract may reference a void transaction in such a way so as to require the parties to proceed as if it were valid, for example for the purpose of paying damages. This effect may be compared to the 'synthetic' replication of rights and obligations, a technique which is widely deployed across the financial markets. ${ }^{80}$ It is likely, however, that this outcome would be unexpected in many contexts. This is one reason that a great deal turns on the court's interpretation of the actual words that the parties use in their valid contract and on the other types of external limits to contractual estoppel, considered in the next part of the paper.

In other cases, it is the status of the relevant statements, rather than the contract itself, that is called into question. In Taberna Europe CDO II plc v Selskabet AF1, the Court of Appeal held that contractual estoppel did not arise because the relevant statements were made in an investor presentation intended for use in a marketing 'road show' rather than in the contract between the parties. As a result, the purported disclaimer appeared in the 'very document which is said to contain the misrepresentation on which Taberna relies' 81 and contractual estoppel was therefore not relevant on the facts.

Finally, it has also been argued in a small number of recent cases that particular categories of contractual statements, including those labelled as 'representations', may not have contractual force and therefore may not give rise to contractual estoppel. In Thornbridge, for example, counsel for the claimant company argued that 'representations' in the ISDA MA (including statements about non-reliance, understanding the transaction, and the non-fiduciary status of the parties) $)^{82}$ 'are not contractual warranties and therefore contractual estoppel does not apply'. ${ }^{83}$ Counsel offered Peekay as authority for this distinction, but the judge held that this authority was not, in fact, supportive of this submission. ${ }^{84}$ In the end, the argument was decisively dismissed. Referencing both Springwell and Peekay, the judge concluded that 'this distinction is without substance'. ${ }^{85}$ Citing the first instance decision of Gloster J in Springwell, 86 the judge defined the basis for contractual estoppel as a contractual statement which forms 'the agreed and binding basis on which the parties will conduct their dealings'. ${ }^{87}$ In a more cautious decision on the same point, in Stichting Vestia Groep, the judge held that the SHA had given certain warranties in the relevant 'Additional Representations'

\footnotetext{
${ }^{80}$ For example, a synthetic collateralised debt obligation 'replicates through the use of derivative techniques the economic effect of a more traditional structure based on actual debt and loan obligations (hence the tag 'synthetic').' J. Castagnino, Derivatives: The Key Principles (Oxford: OUP, 3rd ed, 2009) 93. 81 Taberna Europe CDO II Plc v Selskabet (formerly Roskilde Bank. A/S) (in bankruptcy) [2016] EWCA Civ 1262 at [19].

82 Set out at Thornbridge Ltd v Barclays Bank. Plc [2015] EWHC 3430 at [98].

83 Ibid at [99].

${ }^{84}$ Ibid at [101]

${ }^{85}$ Ibid at [103]

86 JP Morgan v Springwell Navigation Corp [2008] EWHC 1186 (Comm) at [567], cited in Thornbridge Ltdv Barclays Bank Plc [2015] EWHC 3430 at [103]. The judge noted that the Court of Appeal in Springwell at [170] provided 'further authority (if needed)' on this point.

87 Thornbridge Ltd v Barclays Bank. Plc [2015] EWHC 3430 at [103].
} 
in the ISDA MA and contractual estoppel arose from them. ${ }^{88}$ In Richards $v$ Wood and Wood, the relevant statement was described as a recital by the Court of Appeal. Indeed, the binding effects of the statement was described as the traditional function of recitals' ${ }^{89}$ The distinction drawn by counsel in Thornbridge has not, therefore, prevented contractual estoppel arising in the authorities to date. The point must come down to the court's view of the parties' intentions in each case, but against this background, it is important to recognise that Springwell was clear that statements in contracts, including representations, can give rise to contractual estoppel if a party intended to be 'bound contractually to its statement, or acknowledgement'. 90

\subsection{DEFINED BY THE CONTRACT}

Assuming that there is a valid contract in place and that it includes the relevant statements from which an estoppel is alleged to arise, the effects of any contractual estoppel will be defined by the relevant words. Addressing the effects of contractual estoppel often takes place as part of the court's broader assessment of the effects of a contract's terms, in particular if it is alleged to arise in relation to certain 'defensive drafting'. This is a sign that contractual estoppel is now being treated as an integral part of broader contract law, as was clearly the case in First Tower Trustees. ${ }^{91}$ Here, the judge set out a three-stage test in order to determine the effects of certain clauses in a Lease and an Agreement for a Lease, comprising

(i) Construction

(ii) Basis clause or exclusion clause and

(iii) Reasonableness. ${ }^{92}$

Notably, the judge held that he had included stage (ii) in this test because it 'arises from the decision of the Court of Appeal in Springwell v JP Morgan'.93 In practice, each of these stages (whether they are applied in the form of this three part test or more informally) provides the courts with the opportunity to regulate the effects of contractual estoppel.

Stage (i) of the test is important because contractual estoppel arises only to the extent of the relevant and permissible words in any given contract. Depending on the type of clause being construed, the approach may be expressly shaped by the authorities on exclusion and limitation clauses. ${ }^{94}$ The starting point, as with

${ }^{88}$ Credit Suisse International v Stichting Vestia Groep [2014] EWHC 3103 (Comm) at [303] and [317].

${ }^{89}$ Richards $v$ Wood and Wood [2014] EWHC Civ 327 at [15].

90 Springwell Navigation Corp v JP Morgan Chase Bank [2010] EWCA Civ 1221 at [170].

${ }^{91}$ First Tower Trustees Ltd v CDS (Superstores International) Ltd [2017] EWHC 891 (Ch).

92 Ibid at [28].

${ }^{93}$ Ibid at [30]. Case reference included in the original but omitted from the quote.

${ }^{94}$ Such as Axa Sun Life Services Plc v Campbell Martin Ltd which involved an analysis of an exclusion clause, where Rix LJ stated that: 'No doubt all such cases are only authority for each clause's particular wording: 
any exercise in contractual interpretation, is that the words of each contract must be construed in its own right. In reality, however, as demonstrated above, authorities on certain, widely used defensive drafting have become influential during the interpretation stage. The terms considered in Springwell, in particular, often provide a point of reference for the analysis of defensive drafting. ${ }^{95}$

The most significant problem for parties asserting contractual estoppel is that the drafting in question is found to be narrower than they are arguing for, so that even though estoppel may arise, it fails to cover the issue in question. Accordingly, it has been held that where a contract included a clause stating that 'no representations' had been made to investors by the sellers of a property investment scheme, ${ }^{96}$ these words did not cover the seller's 'promises as to how the scheme was to operate' that were in issue in the case. These promises, for example about the seller's future plans to deal with the planning authorities, were not 'statements of an existing state of affairs such as would be covered by the term "representations". ${ }^{97}$ Nor were they found to be a representation in the sense of being 'a statement about a state of mind, such as an intention'. ${ }^{98}$ Therefore, the coverage of the clause was too narrow to protect the seller, and these particular arguments were not considered in the subsequent appeals. ${ }^{99}$

Stage (ii) of this test categorises clauses as basis or exemption clauses, while stage (iii) follows if clauses are categorised as exclusion clauses, the validity of which will be subject to the reasonableness test set out in UCTA. Importantly, the burden of showing that the exclusion clause meets this test will be on the party seeking to exclude or limit liability.

Recent cases attempting to determine if a particular clause is a basis or an exclusion clause tend to navigate by Springwell, though this does not always ensure a consistent approach. In that case, certain terms were found by the Court of Appeal to be basis clauses (e.g., those stating that there was no advisory relationship) while others were exclusion clauses (e.g., non-reliance clauses) and

\footnotetext{
nevertheless, it seems to me that there are certain themes which deserve recognition. Among them is that the exclusion of liability for misrepresentation has to be clearly stated.' [2011] EWCA Civ 133 at [94]. Quoted, for example, in Roberts v Egan [2014] EWHC 1849 (Ch) at [58].

${ }^{95}$ For example, in First Tower Trustees part of the analysis was expressly influenced by the decision in Springwell on the basis 'the Court construed a very similar clause to the present' First Tower Trustees Ltd $v$ CDS (Superstores International) Ltd [2017] EWHC 891 (Ch) at [31].

96 Financial Conduct Authority (formerly Financial Services Authority) v Asset LI Inc (trading as Asset Land Investment Inc) and ors [2013] EWHC 178. The representations clause is set out at [70] and considered further in Part 4 of the paper. The judge's decision that a property investment scheme did fall within the definition of a collective investment scheme within the meaning of section 235 of the Financial Services and Markets Act 2000 was upheld by the Court of Appeal in Financial Conduct Authority (formerly Financial Services Authority) v Asset LI Inc (trading as Asset Land Investment Inc) and ors [2014] EWCA Civ 435 and by the Supreme Court in [2016] UKSC 17. This meant that the arguments about the effect of the no representation clauses fell away at appeal. However, writing for a unanimous Court of Appeal, Gloster LJ stated, 'if it were necessary to do so, I would support the conclusions of the judge in relation to these issues.' Financial Conduct Authority (formerly Financial Services Authority) v Asset LI Inc (trading as Asset Land Investment Inc) and ors [2014] EWCA Civ 435 at [99].

97 Financial Conduct Authority (formerly Financial Services Authority) v Asset LI Inc (trading as Asset Land Investment Inc) and ors [2013] EWHC 178 at [118].

98 Ibid.

99 Ibid at [120].
} 
therefore subject to UCTA. However, as the judge identified in First Tower Trustees, a number of first instance decisions claiming to follow Springwell in order to categorise similar non-reliance clauses disagree with one another. ${ }^{100}$ Tellingly, many first instance decisions hedge their bets, to the extent that they find that clauses are basis clauses but go on to address the position should this classification be incorrect.

In the context of the classic cases described above, little in fact turns on the classification of these terms, because the court is very unlikely to find that a clause in a standardised contract, well-known to both users, who have expertise in the markets and access to legal advice, is unreasonable for the purposes of UCTA. In Raiffeisen Zentralbank, for example, the judge described 'the undesirability, generally speaking, of striking down terms freely agreed between large commercial parties'. ${ }^{101}$ By contrast, in Crestsign (a mis-selling case involving a retail client) the judge held that had the relevant clauses been classified as exclusion clauses they would not have been reasonable. ${ }^{102}$ This was due to a long list of factors, including that the market in derivatives was poorly understood by customers such as the claimant, the banks engaged in "'hard sell"" 103 of the products, expert advice was not available to the customer, and because 'defects subsequently found by the FSA in its pilot findings in $2012 \ldots$ afflicted this particular transaction'. 104 There was, for example, 'poor disclosure of exit costs' and a mismatch between the maturity of the loan and the derivative.

It would be wrong, however, to overstate the value of UCTA even for retail customers involved in mis-selling claims. For a start, the judge in Crestsign held that the relevant statements were all basis clauses, ${ }^{105}$ not exclusion clauses, and so the comments about UCTA were obiter. Furthermore, in Thornbridge, the judge found that as 'the authorities on this point are very clear' the clauses in that case were also basis clauses, and that 'no question of reasonableness arises'. 106 Were UCTA to have applied in that case, notwithstanding that the statements in question were in the ISDA MA which was unfamiliar to the retail customer, the judge stated that the clause would not be held to be unreasonable. ${ }^{107}$ Exactly the same decision was arrived at in Sears $v$ Minco, ${ }^{108}$ involving a more sophisticated individual investor who had entered into a standard form share subscription agreement. The

\footnotetext{
100 First Tower Trustees Ltd v CDS (Superstores International) Ltd [2017] EWHC 891 (Ch) at [31] and [32], referring to Thornbridge v Barclays Bank [2015] EWHC 3430 (Ch) and Sears v Minco [2016] EWHC 433 (Ch). 101 Raiffeisen Zentralbank v RBS [2011] 1 Lloyd's Rep 123, at [321], cited in Crestsign Ltd v National Westminster Bank Plc and RBS [2014] EWHC 3043 (Ch) at [101].

102 Crestsign Ltd v National Westminster Bank Plc and RBS [2014] EWHC 3043 (Ch) at [119].

${ }^{103}$ Ibid at [120].

${ }^{104} \mathrm{Ibid}$ at [121]. The judge does not reference this report but is probably referring to Financial Conduct Authority, Interest Rate Hedging Products: Pilot Findings (March 2013), available at http://www.fsa.gov. $\mathrm{uk} /$ pubs/other/interest-rate-swaps-2013.pdf (last accessed on 1 June 2017).

105 Crestsign Ltd v National Westminster Bank Plc and RBS [2014] EWHC 3043 (Ch) [117].

106 Thornbridge Ltd v Barclays Bank Plc [2015] EWHC 3430 at [111] and [112].

107 Ibid at [117].

108 Sears v Minco [2016] EWHC 433 (Ch).
} 
additional reasoning provided here was that finding this particular term to be invalid would potentially be 'unreasonable and unfair to the other participants' in the placement of shares, ${ }^{109}$ so that avoiding third party effects appears to have been a factor in this case.

However, one type of contractual estoppel case from the 'non-financial' category stands out for the way in which the UCTA reasonableness test has been applied. Where contractual estoppel is alleged to arise from non-reliance clauses in contracts for the disposition of land, the courts have begun to apply the reasonableness test in a structured and consistent way based the approach in FoodCo $v$ Henry Boot, ${ }^{110}$ which in turn considered the validity of a non-reliance clause in an agreement for a lease. In this case, Lewison J, citing Peekay, ${ }^{111}$ held that the particular clause was capable of giving rise to a contractual estoppel. The litigants having accepted that the clause had to satisfy the test of reasonableness, the judge went on to conclude that he was in 'no doubt' that the clause passed this test. ${ }^{112}$ Five reasons were given, which have become influential in later cases.

i) The aspiration of certainty is a reasonable one for the parties to adopt ...

ii) There was no substantial imbalance of bargaining power between the parties...

iii) Each of the tenants was advised by solicitors...

iv) The term itself was open to negotiation...

v) Perhaps most importantly, the clause expressly permitted reliance on any [written] reply given by [the landlord]'s solicitors to the tenant's solicitors. If, therefore, something of importance had been stated in the course of negotiations upon which the intending tenant wished to rely, its solicitors had only to ask [the landlord]'s solicitors for an answer to a question. That would have revealed whether [the landlord] was prepared to formalise the statement so that the tenant could rely on it or whether the tenant would have to undertake its own due diligence. ${ }^{113}$

This approach has been influential in subsequent contractual estoppel cases involving land. The same five factors were applied one-by-one in the course of Hardy $v$ Griffiths, with the conclusion again being reached that the non-reliance clause (in the contract for the sale of land incorporating the Standard Conditions of Sale (4th ed)), was a reasonable one. In First Tower Trustees, the same five reasons lead to a different outcome as regards a clause in a Lease. Importantly, this clause did not allow for what the judge called 'permitted reliance"114 which refers to a carve-out in a non-reliance clause for certain pre-contractual information provided

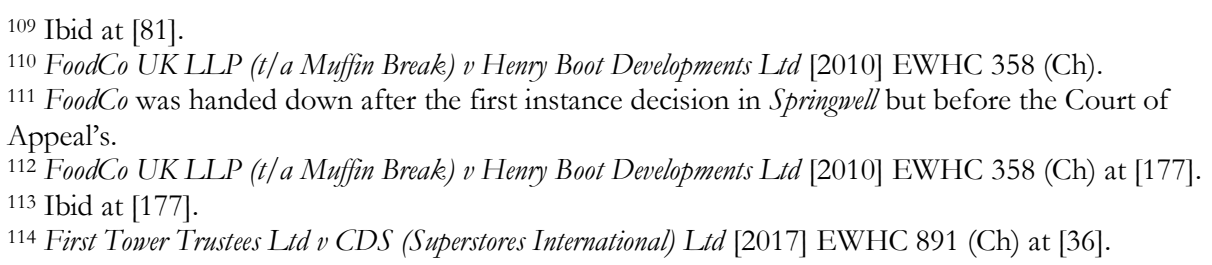


by the representor. Specifically, the non-reliance clauses in FoodCo and Hardy, and a different clause also considered in First Tower Trustees, all allowed a tenant to rely on written answers provided by the landlord's solicitors. The absence of 'permitted reliance' was held by the judge in First Tower Trustees to be a strong indication of unreasonableness, not least as it rendered pre-contractual enquiries 'worthless' and 'positively misleading'.115 Moreover, the judge held that practitioners in this area would likely be 'appalled if such clauses gained currency and were upheld by the courts.'116

Nothing in FoodCo, or the later Court of Appeal decision endorsing this approach, ${ }^{117}$ or in the two subsequent authorities discussed above, expressly restricts this approach to reasonableness to contracts involving land. Indeed, there seems to be no reason to confine these authorities to this context, any more than the Springwell and Peekay decisions have been confined to cases involving certain terms used in banking. These five factors would be a valuable framework for the courts to reference when analysing exclusion clauses in different contexts and reference to them would help to maintain consistency between the diverse contractual estoppel cases which this paper has identified. While the fifth factor (permitted reliance) may seem tailored to non-reliance clauses in contracts for land, the weight given to it should depend on the market view in any given sector, as in fact indicated in First Tower Trustees itself. For example, in a case involving a standardised financial contract, the absence of 'permitted reliance' is almost certainly going to be expected by participants and be found to be perfectly reasonable. However, in a context where a contractual counterparty is encouraged to undertake pre-contractual due diligence but the lack of 'permitted reliance' risks making the exercise worthless, this factor suggests that the clause would be less likely to be upheld as a reasonable one.

Finally, the notion of 'permitted reliance' is helpful for drafters as well as litigators. Here is a way for those negotiating contracts to qualify non-reliance clauses, which has the advantages of formalising pre-contractual negotiations, clarifying what information a representee may rely upon, and increasing the likelihood of a clause being found to reasonable under UCTA. At the same time, this approach does not introduce any uncertainty around the status of oral representations or even around written representations provided outside of the identified procedure identified (e.g. as part of marketing materials) and it therefore preserves the core value of the non-reliance clause. For these reasons, 'permitted reliance' is a useful notion for both courts and for practitioners, and good example of non-financial cases involving contractual estoppel offering lessons which transcend their specialist contexts.

115 Ibid at [38].

116 Ibid at [40].

117 Lloyd v Browning [2013] EWCA Civ 1637 at [35]. 


\section{EXTERNAL LIMITS}

The spread of Springwell estoppel into more diverse areas of business and personal life has focused attention on the external limits to the doctrine, meaning those limits which apply exogenously to the contract. This part of the paper considers the current status of these limits. The issues are considered in descending order of certainty about their effects on contractual estoppel, from fraud as having clearest effects, to public policy as the most under-developed limit to date.

\subsection{FRAUD}

Fraud is to contractual estoppel as Kryptonite is to Superman, namely the single factor which always leads to defeat. As one of the 'non-financial' cases identified in Part 2 puts it, '[t]here is a well-known principle of law that fraud is a thing apart." 118 Such debates as there on this point are about marginal circumstances which may or may not count as fraud for these purposes, rather than about the effects of fraud itself.

It is clear, therefore, that contractual estoppel arising from defensive drafting cannot prevent a claim for fraudulent misrepresentation. Some litigants therefore confine their case to fraudulent misrepresentation ${ }^{119}$ while others are forced to, once the contractual estoppel issue has been decided against them. ${ }^{120}$ This also means that an allegation of fraud can defeat an application for summary judgment based on a contractual estoppel. ${ }^{121}$ In one recent case, a bank simply dropped the part of its case based on contractual estoppel once a claimant had introduced the allegation of fraud. 122

Given the seriousness of the allegation, fraud is justifiably difficult and burdensome to establish. Before any trial, a claimant pleading fraud has to fulfil the extra requirements set out in the Civil Procedure Rules ${ }^{123}$ by setting out the allegation in the Particulars of Claim so that it is 'distinctly alleged ... [and] sufficiently particularised'124 in order that the defendant can understand the case he has to meet. This requirement is enforced rigorously. In one of the cases considered above, a claimant's failure to amend its Particulars of Claim correctly provided one of the grounds on which the defendant was granted summary judgment. ${ }^{125}$ If the case proceeds to trial, it is a heavy burden to persuade the court that, on the evidence, the representor made the representation with the required

\footnotetext{
118 Bonhams v Cavazzoni [2014] EWHC 682 (QB) at [10].

119 UBS AG v Kommunale W asserwerke Leiprig AG GmbH [2014] EWHC 3615 (Ch) at [642].

${ }^{120}$ FoodCo UK LLP (t/ a Muffin Break) v Henry Boot Developments Ltd [2010] EWHC 358 (Ch) at [178].

121 Bonhams v Cavazzoni [2014] EWHC 682 (QB) at [31].

122 Bank Leumi (UK) Plc v Akrill [2014] EWCA Civ 907 at [25]-[27].

123 Civil Procedure Rules, Rule 16, Practice Direction 8.2(1).

124 Three Rivers DC v The Governor and Company of the Bank of England No 3 [2003] 2 AC 1, quoted in FoodCo $v$ Henry Boot [2010] EWHC 358 (Ch) at [179].

125 Startwell Ltd v Energie Global Brand Management Ltd [2015] EWHC 421 (QB) at [77].
} 
subjective state of mind, described in Derry $v$ Peek as when 'a false representation has been made (1) knowingly, or (2) without belief in its truth, or (3) recklessly, careless whether it be true or false.' 126 In FoodCo, after lengthy inquiry, none of the many alleged representations was found to be fraudulent, because the Court held that the landlord had an honest belief in the truth of the statements; merely lacking reasonable grounds for such a belief was held not to be enough to amount to fraud. ${ }^{127}$ In $U B S v K W L$, none of the fraudulent representations alleged by KWL was found to have been made (though other defences based on bribery and conflict of interest succeeded in this case). ${ }^{128}$

Because, on the one hand, fraud has such powerful and stigmatising effects and, on the other, it is so onerous to establish, there are relatively few full trials in this area which consider the issue. Nonetheless, recent interim decisions indicate that there remain a few arguable points about the impact of fraud in this area. First, where there is a fraud which is known at the time of a making a settlement agreement, it has been argued that this prevents the innocent party from rescinding the agreement for fraud later on. This point was recently raised during an interim application, though not ultimately decided by the judge. Nonetheless, it was apparent in the decision that any such effects would require a clear mutual understanding of the fraud ex ante (missing in this case) ${ }^{129}$ and clear intention in the agreement. Secondly, where it was argued that a 'non-reliance' basis clause meant that no representation of any kind could be taken into account by the court, a counter argument was that a basis clause could not be valid where it was signed because of a dishonest representation. In the context of a summary judgment application, this was held to be arguable. ${ }^{130}$ In practice, the issue must turn on the nature of any pre-contract statements about the clause in question as well as the wording of the clause itself. However, it must be possible that in certain circumstances a clause would invalidated in this way, and contractual estoppel would therefore not arise. As established earlier in the context of the discussion of rectification, contractual estoppel will always be subject to the correct and valid terms of the parties' agreement.

\subsection{STATUTE}

The relationship between contractual estoppel and statute has been thrown into focus by three recent cases from the 'diverse financial' category described above. The issues at stake here differ from the debate around the applicability of the reasonableness test in UCTA. While UCTA regulates certain clauses which may

\footnotetext{
126 Derry v Peek (1889) L.R. App 13 App Cas 337, 374 per Lord Herschell quoted in FoodCo v Henry Boot [2010] EWHC 358 (Ch) at [189].

${ }^{127}$ FoodCo v Henry Boot [2010] EWHC 358 (Ch) at [251].

128 UBS v KWL [2014] EWHC 3615 (Ch) at [646]-[676] and [697].

129 Bonbams v Cavazzoni [2014] EWHC 682 (QB) at [14].

130 Deutsche Bank v Unitech [2013] EWHC 2793 (Comm) at [173].
} 
give rise to a contractual estoppel, the issues here are whether a specific contractual relationship should be regulated by a given statute or not, and the extent to which contractual estoppel should play a role in answering that question.

A great deal in these cases depends on the interpretation of the particular statutory provision in question, ${ }^{131}$ but it is possible to identify a common theme in the recent cases, which is that contractual estoppel should not play a role in determining whether a relationship is in fact a regulated one. In practice, however, these have proved difficult issues for the courts to grapple with, as evidenced by the facts that the cases throw up many issues aside from the impact of contractual estoppel (though that is the focus of the discussion here), that one case proceeded to the Supreme Court, and that two others involved the Court of Appeal overturning first instance decisions.

Two such cases concerned the applicability of the Consumer Credit Act 1974 ('CCA'), which, amongst other provisions, imposes protective legal procedures in the context of certain consumer loans. In Wood v Capital Bridging Finance Ltd, Mrs Wood had signed a loan facility agreement which included declarations that the loan was for the purpose of a business carried on by her, and that the loan was unregulated by the CCA. In fact, the loan was not for her business, but to finance one run by her son-in-law, and for technical reasons this meant that the loan should have been regulated by the CCA. This mattered as Mrs Wood's loan was in default, and a lender's rights are significantly modified under a regulated loan as compared to its position where it is making a 'simple contractual claim'. ${ }^{132}$

The Court of Appeal unanimously upheld the borrower's appeal, primarily because the lender's employee knew that the loan was for Mrs Wood's son-in-law. Amongst other arguments, the lender had asserted that contractual estoppel arose from Mrs Wood's contractual declarations, so that she was estopped from denying that the loan was unregulated. Notably, while other types of estoppel were unavailable because of the lender's lack of detrimental reliance, (knowing as it did that the loan was not for Mrs Wood's own business), as Springwell established, this did not affect the possibility of contractual estoppel arising. Nonetheless, the Court of Appeal found that contractual estoppel did not arise in this case, because if it had done, it would be giving 'contractual effect to a declaration ... in what is otherwise a regulated agreement that it is not a regulated agreement'. ${ }^{133}$ 'The Court found that such a 'contractual effect' could not 'prevail against the clear

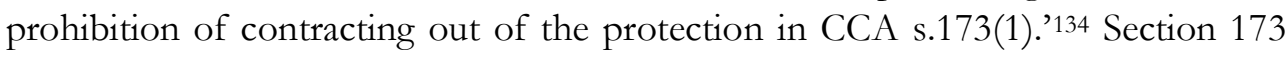
states that 'a term ... is void if, and to the extent that, it is inconsistent with a

131 For example, see Littlewoods Retail Ltd v The Commissioners for HMRC [2014] EWHC 868 (Ch) at [229][242] where the judge rejected the argument that contractual estoppel arose from a settlement agreement so that HMRC would be held to an implied statement that VAT was not due. This was because the settlement agreement in question was regulated by section 85 of the Value Added Tax Act 1994. The regulatory scheme was inconsistent with the contractual estoppel argued for, and the judge held that, on the basis of the language of section 85, Parliament did not intend ordinary contract law to apply in parallel.

132 Wood v Capital Bridge Finance Ltd [2015] EWCA Civ 451 at [2].

133 Ibid at [31].

134 Ibid at [30]. 
provision for the protection ... contained in this Act or in any other regulation made under this Act.' 135 The decision therefore requires the word 'term' in the CCA to be read broadly to include the 'contractual effect' of the estoppel, but it is clearly in keeping with the underlying purpose of section 173.

In a test case handed down shortly after $W$ ood, a differently constituted Court of Appeal considered the status of loans made by Northern Rock to 41,000 borrowers, tackling the opposite problem to the earlier case. In NRAM plc v McAdam ${ }^{136}$ loan documents expressly stated that the transactions were regulated by the CCA when in fact, each loan fell outside the parameters of the Act because the sums involved exceeded the maximum set out in the statute. ${ }^{137}$ Regulated loans are subject to many 'highly technical provisions' 138 but the real significance in this case was that from October 2008, lenders under regulated agreements had to provide prescribed periodic statements to borrowers. NRAM had failed to do so between 2008 and 2012 and the statutory scheme provided that for the period of non-compliance, a borrower under a regulated agreement would have no liability for interest or any default sum. If the loan agreements in question were regulated, NRAM would therefore have had to refund some $£ 258$ million. ${ }^{139}$

At first instance, the judge held that the loans should be treated if they were regulated under the CCA. This decision was overturned on appeal, though the Court of Appeal additionally found that the statements that the loans were regulated amounted to representations and also contractual warranties, thereby entitling the borrowers to sue for misrepresentation and breach. Contractual estoppel was a minor feature of the case, raised by the borrowers alongside other forms of estoppel, but it triggered a revealing discussion at the Court of Appeal level. The judge at first instance had found that the shared assumption in the contract was capable of giving rise to an estoppel by convention and/or a contractual estoppel.140 The Court of Appeal disagreed because of the construction of the relevant statements, but also because it held that, on the basis of the relevant authorities, NRAM cannot be estopped from asserting that the loan agreement is not in fact regulated or that the borrowers do not enjoy the rights conferred by the 1974 Act.' 141 While parties can therefore choose to import particular statutory protections into unregulated contracts, ' $[$ t] he scope of any estoppel cannot in our judgment extend any wider': 142 in other words, they cannot import the effects of an Act on a wholesale basis.

\footnotetext{
135 Section 173(1) of the Consumer Credit Act 1974. Emphasis added.

136 [2015] EWCA Civ 751.

137 The Consumer Credit Act 2006 removed this ceiling for loans entered into after 6 April 2008.

138 NRAM v McAdam [2015] EWCA Civ 751 at [18].

139 Ibid at [1]-[7].

140 NRAM v McAdam [2014] EWHC 4174 (Comm) at [29]-[30], where the judge also noted that this finding was subject to the argument that estoppel could not be used as a sword, but only as a shield. Given his main findings, this issue did not have to be addressed.

141 NRAM v McAdam [2015] EWCA Civ 751 at [54].

142 Ibid.
} 
This part of the decision seeks to uphold what Gloster LJ (the first instance judge in Springwell, here writing the unanimous decision of the Court of Appeal in $N R A M)$ calls 'the legal reality of the position', 143 namely that the loans were unregulated despite the contractual statements to the contrary. This approach is strongly echoed in a recent Supreme Court case considering the classification of a deal for the purpose of financial regulation, Financial Conduct Authority v Asset LI Inc. ${ }^{144}$ Here, the Supreme Court was required to decide if a 'so-called land-banking arrangement' ${ }^{145}$ fell within the definition of a collective investment scheme under section 235 of the Financial Services and Markets Act 2000 ('FSMA'). If so, it would have meant that the seller was operating in breach of section 19 of FSMA, the general prohibition on conducting a regulated activity without being authorised or exempt, which carries very serious sanctions.

The seller made a series of arguments as to why the scheme fell outside section 235. Contractual estoppel was addressed at first instance only, because all of the seller's principal arguments failed decisively. What is important for this purpose is the courts' emphasis, which echoes the observations of Gloster LJ in $N R A M$, that they must look beyond the 'strict view of the legal rights and duties of the parties'146 to the 'overall realities of the scheme as it is designed to operate in practice and as it is presented to investors'. ${ }^{147}$ Thus, words spoken on the phone to individual investors may not have had the legal force of contractual terms, but they should be taken into account as 'parallel non-contractual arrangements' because

People do not live their lives only by reference to their legal rights, and often manage their affairs, and make arrangements, on the basis that the legal framework in which they operate will not be invoked, or is unlikely to be invoked. ${ }^{148}$

Importantly, this approach is not an express requirement of section 235 itself, but it follows that set out in two previous case on the section. ${ }^{149}$ It was also, at first instance anyway, reinforced by the judge's general observations about how business is done, including that

it is, in my judgment, wrong to regard arrangements (either in the context of section 235 or more generally) as inchoate or imperfect contracts that are

143 Ibid at [54].

144 [2016] UKSC 17.

145 Financial Conduct Autbority v Asset LI Inc [2016] UKSC 17 at [8].

146 Financial Conduct Authority v Asset LI Inc [2014] EWCA Civ 435 at [98].

147 Ibid.

148 Financial Conduct Authority v Asset LI Inc [2013] EWHC 178 (Ch) at [164] per Andrew Smith J.

149 Sky Land Consultants plc [2010] EWHC 399 (Ch), cited by Financial Conduct Authority v Asset LI Inc [2016] UKSC 17 at [13]-[20] and Financial Services Authority v Fradley [2006] 2 BCLC 616 (Court of Appeal), which the Court of Appeal in Financial Conduct Authority v Asset LI Inc [2014] EWCA Civ 435 considered and agreed with at [45]-[46]. 
displaced if the parties enter into a different (perhaps superior) form of understanding, a contract ... Much business is done on this basis ... ${ }^{150}$

These cases therefore show that the courts will treat contractual statements differently in the classic, private law cases such as Springwell, and in cases where statute is involved. In the former, the courts consistently uphold the contracting parties' ability to govern their affairs by reference to a predictable and certain contractual regime. By contrast, the latter cases, to date, have seen a broadly informed 'legal reality' prioritised over the state of affairs described in a contract. Specifically, the courts have endeavoured to ensure that parties do not avoid statutory rules where their contracts do not reflect the reality of their relationship. This is not to read too much into this latter group of cases: as already emphasised, the outcome in any given case will depend on the particular agreement and statute involved. Nonetheless, the evidence to date suggests that the courts will be prepared to look beyond the parties' contract when interpreting and applying statutory protections, and that contractual estoppel will not be allowed to disrupt their analysis.

\subsection{PUBLIC POLICY}

This is the most ill-defined of the external limits to contractual estoppel, but it is arguably the most important way in which individuals in certain types of one-sided relationships are protected from the doctrine. 'Public policy' is treated by the courts as transcending case law, but it is nonetheless dependent on authorities to the extent that they flesh out how it applies.

In First Subsea Ltd v Balltec Ltd, contractual estoppel was not permitted to circumvent public policy checks on employment contracts. Here, an employment contract contained a restraint of trade restriction, with the next clause stating that the parties considered the clause to be 'fair, reasonable and necessary to protect the goodwill and interests of [the employer]'. ${ }^{151}$ The employer argued in court that the second clause created a contractual estoppel which circumvented the ordinary requirement that such covenants were not enforceable on public policy grounds, unless employers could establish that they were of a permitted type. The judge rejected this argument on the basis that '[w] hat matters is not whether the parties think that the terms are fair but whether the law accepts the terms as fair. So I will embark on that enquiry.' ${ }^{152}$

It has also been held that contractual estoppel cannot be used to impose a liability on an entity which had stated that it would facilitate a party's access to a

\footnotetext{
150 Financial Conduct Authority v Asset LI Inc [2013] EWHC 178 (Ch) at [164] per Andrew Smith J.

Emphasis added by the author.

151 First Subsea Ltd v Balltec Ltd [2014] EWHC 866 (Ch) at [279].

152 Ibid at [280] (emphasis in the original). Though it was not mentioned in the case, this decision is consistent with that in Dinsdale Moorland Services Ltd v Evans [2014] 2 Costs L.R. 217.
} 
pension to be paid from third party funds. ${ }^{153}$ This case arose out of an employment dispute, and in the settlement agreement the employer stated that the employee would be able to access her full pension, paid from the pension fund, on reaching the relevant age. In fact, it was not within the power of the employer to promise a full pension, and when the employee reached the relevant age, it was refused on other grounds. At first instance, the Pension Ombudsman found that the employer had to make up the difference from its own funds. One of the reasons given was that a contractual estoppel had arisen from the relevant statement in the contract. This decision was overturned on appeal, in part because it held to be flawed to suggest that contractual estoppel could impose a novel personal liability. Though it was not mentioned in the case, this would also seem to be an example (echoing $N R A M$ ) of a claimant attempting to use an estoppel as a sword rather than as a shield and, while the case is unreported, this decision also seems to turn on the limited scope of the underlying statement in the settlement agreement.

Finally, it seems that on the basis of public policy, a party which is a fiduciary due to the nature of its role (such as a trustee, solicitor or doctor) cannot 'cannot escape being treated as one by a term that simply says that that is not what he is'. 154 This outcome must be distinguished from cases where fiduciary status is to be determined on the facts; here, as we have seen, contractual estoppel may arise from statements specifically intended to preclude such a relationship.

In sum, these cases show that contractual estoppel has not been permitted to hollow out rules which protect parties in positions of dependence, such employees and beneficiaries. While the authorities in this area remain piecemeal, such cases as there have been to date have been consistent, upholding public policy as a meaningful external limit on contractual estoppel.

\section{CONCLUSION}

The dominant theme of the recent cases involving Springwell estoppel is consistency. To date, the basic principles set out by the Court of Appeal in this foundational case have been widely applied and uniformly upheld. The core justification of certainty for the contracting parties has been embraced by the courts, to the point where it now even influences the statutory test of reasonableness, on the occasions when that test applies. Over the course of more recent 'second generation' cases, existential questions about the doctrine have

\footnotetext{
153 Police and Crime Commissioner for Greater Manchester v Butterworth (unreported) 10 November 2016. See also N. Tuck, 'High Court overrules PO's decision against Manchester's Police and Crime Commissioner' Pensions Age, 11 November 2016, available at http://www.pensionsage.com/pa/High-Court-overrulesPO-decision-against-Manchester-Police-and-Crime-Commissioner.php (last accessed on 6 June 2017). 154 Regione Piemonte v Dexia Crediop Spa [2014] EWCA Civ 1298 at [117].
} 
faded away, and the doctrine has been gradually absorbed into the general law of contract.

There now seems little doubt that, were a Springwell-esque case to come up for consideration by the Supreme Court, the well-established doctrine would be confirmed. Not least, this would be perfectly consistent with developments in other areas of contract law, which have fully endorsed a robust version freedom of contract. In the context of a recent decision on parties' variation of their contracts, for example, Moore-Bick LJ commented that

The governing principle, in my view, is that of party autonomy. The principle of freedom of contract entitles the parties to agree to whatever terms they choose, subject to certain limits imposed by public policy... ${ }^{155}$

While establishing this important central theme, the paper has also sought to evaluate the impact of recent developments outside the financial markets and consider the current status of the doctrine in closer detail. As noted, the underlying premise of this approach draws on the idea that law, as a social science, involves 'two-way ties' between 'actions and institutions'.156 The objective has therefore been to extract from diverse authorities the nature of new rules regarding contractual estoppel, but also to extract from the doctrine of contractual estoppel a sense of how different aspects of the real world may be shaped by these developments. Overall, this analysis has provided three main insights.

First, the evidence about the very wide use of Springwell estoppel arguments demonstrates beyond doubt the significant impact of the doctrine on contracts, and on disputes about contracts, involving very diverse areas of business and private life. On this basis, it would clearly be wrong to think of Springwell estoppel as a feature of the financial markets or of banking law, though it certainly plays an important role in this sector. Moreover, the paper has shown how contractual estoppel authorities create momentum beyond the courtroom. As several decisions acknowledge, the courts send signals to practitioners when they uphold the effectiveness of particular drafting. On occasions, this reflexivity is expressly recognised by the court, and some decisions are shaped accordingly. ${ }^{157}$ Nonetheless, as the courts continue to review particular clauses from an evergrowing range of sectors, agreements drafted specifically with contractual estoppel in mind will become even more commonplace.

Secondly, though the effects of the increased awareness of contractual estoppel are profound, the doctrine is by no means unchecked. The paper has established that important checks will be found in contracts themselves, and that these will be the principal limits on contractual estoppel in most financial cases. In

155 Globe Motors Inc v TRW LucasV arity Electric Steering Ltd [2016] EWCA Civ 396 at [119].

156 A. Giddens, Social Theory and Modern Sociology (Cambridge: Polity Press, 1987) 30.

${ }^{157}$ For example, in First Tower Trustees Ltd v CDS (Superstores International) Ltd [2017] EWHC 891 (Ch) at

[40] the judge states that he is wary of upholding a clause which may then gain 'wide currency' in practice. 
this context, it has been suggested that a more consistent approach to UCTA reasonableness would benefit the courts and drafters alike, and that this might be based on the idea of 'permitted reliance' understood by reference to accepted practice in a given market. However, the paper has also shown that for many types of parties, and in particular for those beyond the financial markets, more meaningful limits on contractual estoppel lie outside the contract. These take the form of the very clear effects of a claim in fraud, the realistic way in which the courts approach the question of whether protective statutes apply, and, as we are starting to see, public policy, as fleshed out in several recent cases.

Finally, the paper has shown that the recent and more diverse cases on contractual estoppel have implications for the drafters of legislation as well as for the drafters of contracts. On the basis of recent, complex cases about the CCA and other statutes, it is clear that careful thought needs to be given to the effects of contractual estoppel on statute, including on those statutory rules about contracting out, for example. Of course, while any sort of wholesale review of legislation may be unrealistic in practice, the cases also show that less complex regulatory measures may suffice to afford more vulnerable parties a measure of redress, despite the presence of standardised defensive drafting in their contracts; in Thomas, for example, a voluntary code of conduct provided retail customers with a claim against their bank, standard defensive drafting and contractual estoppel notwithstanding. While a review of the potential dynamics between contractual estoppel, legislation and other forms of regulation is a considerable task, this analysis proves that it is an important one, especially because the effects of contractual estoppel are demonstrably not confined to financial contracts or sophisticated parties. Quite the opposite; as the paper has shown, Springwell estoppel has the potential to affect all contracts great and small. 